\title{
Detection of HBs antigen, DNA polymerase activity, and hepatitis B virus DNA in tears: relevance to hepatitis $\mathrm{B}$ transmission by tears
}

\author{
P GASTAUD,' CH BAUDOUIN,' AND D OUZAN ${ }^{2}$
}

From the 'Department of Ophthalmology, Saint-Roch Hospital, Nice, and the ${ }^{2}$ Liver Unit, A Tzanck Institute, Nice, and Inserm U271, Lyon, France

SUMmaRY Hepatitis B surface antigen, DNA polymerase, and hepatitis B virus DNA have been sought in the tears of 72 patients. These markers were detected in a high percentage of hepatitis B carriers, which proves the presence of hepatitis B virus in the tears and raises the question of its eventual transmission in this way. The severity and extreme contagiousness of hepatitis B together with the increasing number of virus carriers justify systematic sanitary rules among ophthalmic clinicians and staff, but vaccination remains the best mean of limiting the spread of the disease.

The recent isolation of human immunodeficiency virus (HIV) from the tears of patients with acquired immune deficiency syndrome ${ }^{1}$ or AIDS-related complex $^{2}$ made ophthalmologists aware of the possible transmission of virus diseases by those secretions. The risk of hepatitis B transmission, however, may be much more important owing to its extreme contagiousness and the increasing number of chronic carriers. Hepatitis B epidemics are well known and rightly dreaded by workers in laboratories and blood transfusion and renal dialysis units, but ophthalmic clinicians are not alert enough to this risk and often neglect it, though it became evident when hepatitis B surface antigen ( $\mathrm{Hbs} \mathrm{Ag}$ ) was detected in tears. ${ }^{3-5}$ But this antigen, located on the virus envelope, is also found on non-infectious particles, so it remained possible that the virus itself did not infect the tears.

Owing to a better knowledge of this virus and to the discovery of new markers of complete replicative forms it is now possible to confirm its presence in tissues or secretions. The aim of this study was to detect in the tears three markers of hepatitis $B$ virus (HBV) - namely HBs Ag, DNA polymerase activity, and viral DNA (HBVDNA) - to analyse the risk of its transmission by ophthalmic patients, and to consider means of preventing that.

Correspondence to Professor P Gastaud, Department of Ophthalmology, Saint-Roch Hospital, 5 rue P Devoluy, Nice, France.

\section{Material and methods}

The tears of 72 patients were sampled by gentle pipetting, without conjunctival bleeding (which might alter the results). $\mathrm{HBs} \mathrm{Ag}$ was detected in tears by an immunoenzyme method (Auszyme Monoclonal, Abbott Laboratories, North Chicago, Ill, USA), on $32 \mathrm{HBs} \mathrm{Ag}$ positive patients: five with acute hepatitis, 15 with active or persistent chronic hepatitis, and 12 asymptomatic carriers. Ten serum HBs Ag negative subjects were used as controls.

DNA polymerase activity was sought in the tears of $20 \mathrm{HBs} \mathrm{Ag}$ positive patients with chronic hepatitis, 10 with high DNA polymerase serum levels, and 10 with insignificant levels. The dosage technique was based on Kaplan's method ${ }^{67}$ and used the measurement of tritiated thymidine incorporation during DNA synthesis. The enzyme specificity was evaluated by dosing its activity with phosphonoacetic acid, which does not inhibit HBV DNA polymerase, and with phosphonoformic acid, which inhibits it. The difference between the two results gave the HBVassociated DNA polymerase value. Results were expressed in counts per minute (cpm). Increase in DNA polymerase activity has been defined as values exceeding $50 \mathrm{cpm}$.

HBVDNA was sought in the serum and the tears of $10 \mathrm{HBs} \mathrm{Ag}$ positive patients with chronic hepatitis by the spot hybridisation technique. ${ }^{89}$ Tears and serum 
were placed on nitrocellulose filters which were hybridised with a radiolabelled ${ }^{32} \mathrm{P}$ DNA probe to detect the presence of HBVDNA. Results were obtained by autoradiography.

Statistical analysis was performed by Student's $t$ test.

\section{Results}

HBs Ag was found in the tears of 21 out of $32 \mathrm{HbS} \mathrm{Ag}$ positive patient (Table 1)-namely, four of five with acute hepatitis $(80 \%), 12$ of 15 with chronic hepatitis $(80 \%)$, and five of 12 asymptomatic chronic carriers $(41 \%)$. The other 11 patients did not have detectable HBs Ag in the tears, though HBs Ag was detected in their serum. This group without detectable $\mathrm{HBs} \mathrm{Ag}$ included two patients with dry eye from whom the collection of tears was somewhat difficult. The tears of the $10 \mathrm{HBs} \mathrm{Ag}$ negative controls were negative.

Abnormal DNA polymerase activity was detected in the tears of all the 10 chronic hepatitis patients with high serum levels of DNA polymerase (Table 2). Tear levels of DNA polymerase were lower than serum values, but the difference was not significant by Student's $t$ test $(t=1.533,0.05<\mathrm{p}<0 \cdot 10)$. In one case DNA polymerase activity was higher in tears than in serum. In contrast, when DNA polymerase was negative in the serum (10 cases), no enzyme activity could be found in tears.

HBVDNA was detected in the serum of three out of $10 \mathrm{HBs} \mathrm{Ag}$ positive patients with chronic hepatitis.

Table 1 Detection of hepatitis B surface antigen in tears

\begin{tabular}{llll}
\hline $\begin{array}{l}\text { Acute } \\
\text { hepatitis }\end{array}$ & $\begin{array}{l}\text { Chronic } \\
\text { hepatitis }\end{array}$ & $\begin{array}{l}\text { Asymptomatic } \\
\text { carriers }\end{array}$ & $\begin{array}{l}\text { HBs Ag negative } \\
\text { controls }\end{array}$ \\
\hline $4 / 5(80 \%)$ & $12 / 15(80 \%)$ & $5 / 12(41 \%)$ & $0 / 10(0 \%)$ \\
\hline
\end{tabular}

Table 2 DNA polymerase activity (cpm) of $H B V$ in the serum and the tears of $10 \mathrm{HBS}$ Ag positive patients with chronic hepatitis. Comparison of mean values obtained in serum and tears appears not to be significant $(t=1.533$, $0.05<p<0 \cdot 1)$

\begin{tabular}{crr}
\hline Patients & Serum* & Tears* \\
\hline 1 & 296 & 176 \\
2 & 1164 & 570 \\
3 & 751 & 512 \\
4 & 1669 & 1528 \\
5 & 1317 & 960 \\
6 & 10210 & 10752 \\
7 & 8111 & 6094 \\
8 & 311 & 162 \\
9 & 290 & 191 \\
10 & 112 & 79 \\
\hline
\end{tabular}

*Negative values below $50 \mathrm{cpm}$.
The tears of these three subjects were also positive for HBVDNA. At the time of the tear collection the other seven patients were negative for HBVDNA, both in serum and in tears. No correlation could be found between positivity for HBVDNA and serum DNA polymerase levels or severity of the chronic hepatitis, since one of the positive cases was considered to be persistent chronic hepatitis and presented negative serum DNA polymerase activity.

\section{Discussion}

Though tears may transmit hepatitis B infection, studies of this subject are few..$^{3.5}$ Given the lack of a direct marker for the virus, only $\mathrm{HBs} \mathrm{Ag}$ detection in tears could be taken as implying a risk of transmission in this way. Nevertheless, HBs $\mathrm{Ag}$, which is a component of the HBV envelope, can also be found in serum and various secretions without infectious particles, so that the significance of its detection in tears may be doubted.

However, $\mathrm{HBs} \mathrm{Ag}$ has been detected in only a few cases ( 30 to $50 \%$ ), of acute or chronic hepatitis. ${ }^{35}$ Till now it had not been found in the tears of asymptomatic carriers. ${ }^{4}$ Our study confirmed in part the previous results on the detection of $\mathrm{HBs} \mathrm{Ag}$ in tears but also showed the presence of the virus in tears owing to the use of specific markers, such as DNA polymerase, a replication enzyme associated with the nucleocapside, ${ }^{10}$ and above all by the virus DNA itself.

Moreover, the high proportion of cases in which these three markers were detected in tears during HBV infection makes the risk of hepatitis B transmission much more important than was previously considered. In our study $\mathrm{HBs} \mathrm{Ag}$ was found in $80 \%$ of cases of acute or chronic hepatitis and was also detected in the tears of asymptomatic carriers. It is the first report on the detection of HBs Ag in the tears of asymptomatic chronic carriers. The discrepancies between our work and previous studies were probably due to the sampling method, as collecting the tears with Schirmer test strips may induce false negative results by absorption of numerous particles. Also noteworthy is the close correlation between serum and tears HBV markers, DNA polymerase and HBVDNA having always been found simultaneously in tears and blood.

As HBV markers were almost constantly present in the tears, all the virus carriers are potentially dangerous. The number of HBV carriers in the population, however, is very high-estimated at $0.5 \%$ in northern Europe, about $2 \%$ in southern Europe, and $15 \%$ in Africa and SE Asia." To these must be added some HBV carriers with nondetectable $\mathrm{HBs} \mathrm{Ag}$ levels. ${ }^{12}{ }^{13}$ The difficulty of detect- 
ing infectious subjects raises a real public health problem which ophthalmologists need to consider.

Hepatitis B is a serious disease leading to death $(1 \%)$ or to a chronic carrier state $(10 \%)$, with frequent development of cirrhosis or hepatocarcinoma. It is highly contagious, the risk being estimated at $30 \%$ after pricking by contaminated material and even $90 \%^{14}$ if the infected blood contains DNA polymerase or $\mathrm{HBe}$ antigen, which is another marker of viral replication. ${ }^{15}$ Transmission is usually by blood and its derivatives, ${ }^{16}$ rarely by secretions (saliva, semen, vaginal fluid, faeces, urine), through a cutaneous abrasion or an apparently healthy mucosa. A study by Bond et al. of hepatitis $B$ infection by plasma inoculation on to the corneal surfaces of a chimpanzee, ${ }^{17}$ and one case of transmission after accidental introduction of infected blood into the eye, ${ }^{18}$ prove that the virus can be transmitted via the conjunctival mucosa or the cornea. Thus HBV infection could be carried from patient to patient by corneal or conjunctival transmission during tonometry, biomicroscopy, or contact lens fitting. HBV infection could be transmitted by this route if a tonometer or a contact lens was used first on an HBV carrier and then placed on a second patient's eye. A model for the spread of virus disease by tonometry exists in epidemic keratoconjunctivitis caused by adenovirus. The risk of HBV transmission through the cornea or the conjunctiva is supported by the previous detection of $\mathrm{HBs} \mathrm{Ag}$ on a tonometer and soft lenses ${ }^{4}$ after contact with the eyes of an HBs Ag positive patient.

Tears, however, may also be dangerous for medical staff, and small cuts or scratches can provide a sufficient portal of entry through the skin for HBV to enter the body. DNA polymerase tear levels being very close to the serum values, the infectivity of tears is probably high. If a quantity as low as $0 \cdot 1 \mu \mathrm{l}$ of plasma can transmit the disease,${ }^{19}$ even small quantities of tears appear to be dangerous, so that strict sanitary rules should be followed. Particular care should be exercised if patients are known $\mathrm{HBs} \mathrm{Ag}$ carriers or are considered to be at high risk of having this infection. High-risk patients include those undergoing renal dialysis, diabetics, drug addicts, and those who have received blood transfusion. However, a clearly indicative clinical context is not always present to warn the ophthalmologists that his patient may be a hepatitis B carrier, so that precautions should always be taken to prevent HBV transmission by tears.

Like HIV, HBV is sensitive to various disinfectants, ${ }^{20}$ such as $80 \%$ alcohol and $5 \%$ sodium hypochlorite, but very high concentrations or temperatures are needed for its destruction. All cleaning and sterilisation methods, however, can ensure efficient prophylaxis against patient-to-patient transmission of HIV and HBV, but are not sufficient to protect the medical staff completely. In practice $\mathrm{HBV}$ vaccination ${ }^{21}$ appears to give the best protection, by injection of purified $\mathrm{HBs} \mathrm{Ag}$. Its efficacy rate reaches $95 \%$ after three injections at one-month intervals. It is well tolerated, and the technique avoids any risk of HIV transmission.

Nevertheless, the growing hepatitis B epidemic together with our detection of $\mathrm{HBV}$ in tears point to the risk of inadvertent HBV transmission by corneal transplantation. The only viral diseases reported to have been transmitted by corneal allograft are rabies $^{22}$ and Creutzfeldt-Jakob disease. ${ }^{23}$ There is so far no clinical or serological documentation of transmission of HIV after corneal transplantation, though corneal allografts from HIV-seropositive donors have been described..$^{24}$ The Eye Bank Association of America, however, recently became aware of a case of possible hepatitis B infection via corneal transplant ${ }^{25}$ and is now recommending HBs Ag screening for all potential corneal donors in addition to systematic HIV detection. $\mathrm{HBs} \mathrm{Ag}$ identification in emulsified corneal tissue from one patient with acute hepatitis $B^{25}$ as well as HIV isolation from the cornea $^{26}$ support the need for screening of all corneal donors for $\mathrm{HBs} \mathrm{Ag}$ and anti-HIV antibodies. If a corneal donor is found to be $\mathrm{HBs} \mathrm{Ag}$ positive, the cornea should not be used for transplantation. If the results of $\mathrm{HBs} \mathrm{Ag}$ screening are known after corneal transplantation, treatment of the recipient with hepatitis B immune globulins and $\mathrm{HBV}$ vaccine should be performed as soon as possible.

Thus the presence of HBV in tears raises problems of public health as well as HIV detection in these secretions. Even if prognosis for hepatitis B is less severe than that for the acquired immune deficiency syndrome, the disease must be taken seriously. The prevalence of HBV carriers and the extreme contagiousness of HBV infection constitute a real danger for ophthalmologists. HBV is not easy to destroy, but correct information together with systematic sanitary rules and more vaccination may help to limit the spread of this severe disease.

\section{References}

1 Fujikawa LS, Salahuddin SZ, Palestine AG, Masur H, Gallo RC. Isolation of human T-Cell leukemia/lymphotropic virus type III from the tears of a patient with acquired immunodeficiency syndrome. Lancet 1985; ii: 529-30.

2 Baudouin Ch, Laffont C, Cottalorda J, De Galleani B, Gastaud P, Lefebvre JC. Isolement du LAV/HTLV III dans les larmes de sujets atteints d'ARC syndrome. J Fr Ophtalmol 1987; 10: 135-9.

3 Darrell RW, Jacob GB. Hepatitis B surface antigen in human tears. Arch Ophthalmol 1978; 96: 674-6.

4 Maass G, Claas W, Schliermann T, Conrads H. Das Risiko einer Übertragung von Hepatitis B durch Kontactlinsenanpassung. Ophthalmologica 1979; 178: 148-55. 
5 Moniz E, Feldman F, Newkirk M, Feinman SV, Berris B. Removal of hepatitis B surface antigen from a contaminated aplanation tonometer. Am J Ophthalmol 1981; 91: 522-5.

6 Kaplan PM, Greenman RL, Gerin JL, Purcell RH, Robinson WS. DNA polymerase associated with human hepatitis B antigen. J Virol 1973; 12: 995-1005.

7 Hantz O, Ooka T, Vitvitski L, Pichoud C, Trepo C. Comparison of properties of woodchuck hepatitis $\mathrm{B}$ virus and human hepatitis B virus endogenous DNA polymerases. Antimicrob Agents Chemother 1984: 25: 242-6.

8 Brechot C, Hadchouel M, Scotto J, et al. Detection of hepatitis B virus DNA in liver and serum: a direct appraisal of the chronic carrier state. Lancet 1981; ii: 765-7.

9 Imazeki F, Omata M, Yokosuka O, Matsuyama Y, Ito Y, Okuda K. Analysis of DNA polymerase reaction product for detecting hepatitis B virus in serum. Comparison with spot hybridation technique. Hepatology 1985; 5: 783-8.

10 Robinson WS, Greenman RL. DNA Polymerase in the core of the human hepatitis B virus candidate. $J$ Virol 1974: 13: 1231-6.

11 Prince AM. Prevalence of serum hepatitis related antigen in different geographic regions. Am J Trop Med Hyg 1970; 19: 872.

12 Cappell R, De Cuyper F, Van Beers D. Diagnosis of hepatitis B by Dane particle associated DNA polymerase assay. J Med Virol 1978; 3: 77-80.

13 Ouzan D, Trepo C. Etude de la replication virale et des manifestations hépatiques dans sept cas de périartérite noueuse associés au virus de l'hépatite B. Gastroenterol Clin Biol 1986; 10: $53-6$.

14 Alter HJ, Seef LB, Kaplan PM, et al. Type B hepatitis: the infectivity of blood positive for e antigen and DNA polymerase after accidental needlestick exposure. N Engl J Med 1976; 295: 909-13.

15 Takahashi K, Akahane Y, Gotanda T, et al. Demonstration of hepatitis Be antigen in the core of Dane particles. $J$ Immunol 1979: 122: 275-9.

16 Schiff ER. Epidemiology of virus B hepatitis. Med Clin North Am 1974; 59: 5904-11.

17 Bond WW, Petersen NJ, Favero MS, Ebert JW, Maynard JE. Transmission of type B viral hepatitis via eye inoculation of a chimpanzee. J Clin Microbiol 1982; 15: 533-4.

$18 \mathrm{Kew}$ MC. Possible transmission of serum hepatitis via the conjunctiva. Infect Immun 1973; 7: 823-4.

19 Barker JF, Murray R. Relationship of virus dose to incubation time of clinical hepatitis and time of appearance of hepatitis associated antigen. Am J Med Sci 1971; 263: 27-33.

20 Abbot JP. Are there methods of sterilization to destroy hepatitis B virus? JAMA 1974: 229: 579.

21 McAuliffe VJ, Purcell HR, Gerin VJ. Type B hepatitis: a review of current prospects for a safe and effective vaccine. Rev Infect Dis 1980; 2: 470-92.

22 Houff SA, Burton RC, Wilson RW, et al. Human to human transmission of rabies virus by corneal transplant. N Engl J Med 1979; 300: 603-4.

23 Manuelidis EE, Angelo JN, Gorgacz EJ, Kim JH, Manuelidis L. Experimental Creutzfeldt-Jakob disease transmitted via the eye with infected cornea. N Engl J Med 1977; 296: 1334-6.

24 Pepose JS, McRae S, Quinn TC, Ward JW. Serologic markers after the transplantation of corneas from donors infected with human immunodeficiency virus. Am J Ophthalmol 1987: 103: 798-801.

25 Raber IM, Friedman HM. Hepatitis B surface antigen in corneal donors. Am J Ophthalmol 1987: 104: 255-8.

26 Salahuddin SZ, Palestine AG, Heck E, et al. Isolation of the human T-cell leukemia/lymphotropic virus type III from the cornea. Am J Ophthalmol 1986; 101: 149-52.

Accepted for publication 7 July 1988. 